\title{
New records of Cracids along a fragmented landscape in Cen- tral Mexico (Aves Cracidae)
}

\author{
Lorena Silverio-Polo', O. Eric Ramírez-Bravo ${ }^{2 *}$, Casimiro Ordóñez-Prado 3 \& Guillermo Ortega Vázquez ${ }^{4}$
}

${ }^{1}$ Sitio Experimental Las Margaritas, Instituto Nacional de Investigaciones Forestales, Agrícolas y Pecuarias, Km 9.5 Carretera Hueytamalco-Tenampulco, Las Margaritas Hueytamalco, Puebla, 73580 México

${ }^{2}$ Grupo de Investigación en Biodiversidad, Alimentación y Cambio Climático, Instituto de Ciencias de la Benemérita Universidad Autónoma de Puebla, Edificio IC 10 Ciudad Universitaria Colonia San Manuel, Puebla, 72570 México

${ }^{3}$ Campo Experimental San Martinito, Instituto Nacional de Investigaciones Forestales, Agrícolas y Pecuarias, Km 56.5 Carretera Federal México-Puebla, San Martinito Puebla, 74100 México

${ }^{4}$ Instituto Tecnológico Superior de Zacapoaxtla, Carretera Acuaco-Zacapoaxtla km 8, Colonia Totoltepec, Zacapoaxtla Puebla, 73680 México

"Corresponding author, e-mail: osvaldoeric.ramirez@correo.buap.mx

ABSTRACT

KEY WORDS
The pava cojolita or crested guan (Penelope purpurascens Wagler, 1830) and the great curassow (Crax rubra Linnaeus, 1758) (Aves Cracidae) inhabit mature rainforests with low or null perturbation, making them potential indicator species. We report actual records of both species obtained through biodiversity monitoring undertaken in the Experimental Site "Las Margaritas" in the municipality of Hueytamalco at the Sierra Nororiental in the State of Puebla. The presence of both species indicates the importance of the Experimental Site "Las Margaritas" for their distribution within a highly fragmented area.

Received 14.09.2018; accepted 25.10.2018; printed 30.12.2018; published online 07.01.2019

\section{INTRODUCTION}

The Cracids (Cracidae) are a family of birds endemic to the neotropics that includes the chachalacas, guans, and curassows, which have a high social and economic value along their distribution (López et al., 2014). However, curassows and guans depend heavily on preserved habitat, which, together with hunting pressure and low reproduction rates (Brooks et al., 1998; Peres, 2000), make them the most threatened bird family in the neotropics (Brooks et al., 2006). Cracid overexploitation has been correlated with human population size and proximity, thus, it is expected that distribution may diminish considerably in these areas (López et al., 2014).
In Mexico, the crested guan (Penelope purpurascens Wagler, 1830) and the great curassow (Crax rubra Linnaeus, 1758) have high economic and social importance due to their value as game birds since they can reach a weight of $2.4 \mathrm{~kg}$ and $4.6 \mathrm{~kg}$ respectively (Del Hoyo, 1994; Howell \& Webb, 1995). Both species inhabit mature forests or those with low perturbation levels and a high proportion of preserved vegetation (Del Hoyo et al., 1994; Pacheco, 1994; González-García \& MartínezMorales, 2010). The biggest threat to both species is habitat destruction and hunting pressure from local communities (González-García et al., 2012).

In contrast, the great curassow is considered vulnerable despite being distributed from Southern 
Tamaulipas, along the Mexican Gulf, to western Colombia and western Ecuador, as it has been extirpated from large parts of its distribution (Howell \& Webb, 1995; Del Hoyo \& Motis, 2004; Hernández-Pérez et al., 2014), particularly: C. rubra rubra from humid forests from eastern Mexico to western Ecuador, and C. rubra griscomi Nelson, 1926 from Cozumel Island (off Yucatán coast of Mexico). Under Mexican legislation, both species are considered as threatened (SEMARNAT, 2010, 2011).

In contrast, the crested guan is considered as a low-risk species by the IUCN due to its widespread distribution that goes from southern Tamaulipas to northern Ecuador (BirdLife International, 2016), particularly: P. purpurascens purpurascens from Humid forests of Mexico to Honduras and Nicaragua, P. purpurascens aequatorialis (Salvadori \& Festa, 1900) from southern Honduras and Nicaragua to western Colombia and southwestern Ecuador, P. purpurascens brunnescens (Hellmayr \& Conover, 1932) from northern Colombia to eastern Venezuela. However, their populations are slowly diminishing (BirdLife International, 2016).

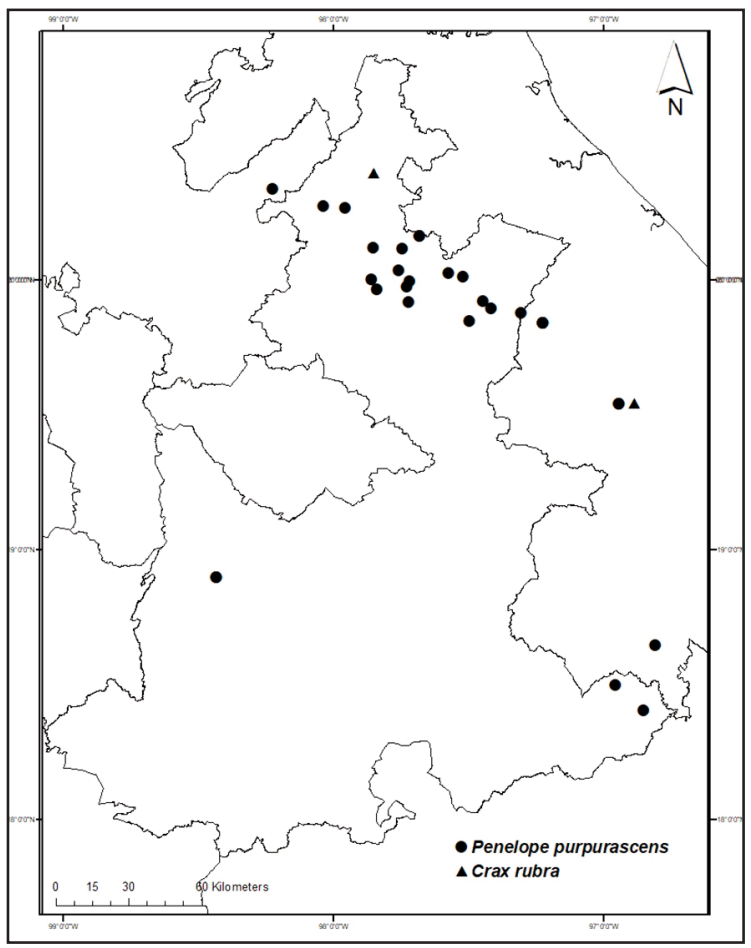

Figure 1. Records of the great currasow (Crax rubra) and the crested guan (Penelope purpurascens).
To produce effective management and conservation plans for populations of both species, it is necessary to generate updated high-resolution information about their distribution (HernándezPérez et al., 2014), as it is considered that viable populations are going to be reduced to protected areas or those with sufficient forest cover (PérezIrineo \& Santos-Moreno, 2017). In this note, we present updated information about the presence and distribution of both species in a highly fragmented zone.

\section{MATERIAL AND METHODS}

Fieldwork was carried out in the Sitio Experimental Las Margaritas which is overseen by the National Institute of Forestry, Agricultural and Livestock Research (INIFAP). It is located in the municipality of Hueytamalco, Puebla in Central Mexico, and it covers a surface of 2,523 ha and an average altitude of $500 \mathrm{~m}$ asl $\left(20^{\circ} 00^{\prime} 05.22^{\prime \prime} \mathrm{N}\right.$, $\left.97^{\circ} 18^{\prime} 28.31^{\prime \prime} \mathrm{W}\right)$ (Fig. 1). Originally, the area was used for livestock research, however, currently there are four main land uses: grasslands (300 ha), bamboo plantations (Guadua aculeata E. Fourn.) (355 ha), secondary forest in different successional stages (1,568 ha), and preserved rainforest (300 ha) (INEGI, 2007). The region has abundant rains during most of the year and a dry season during May-June. Average precipitation is 3,153 $\mathrm{mm}$, and the average temperature is $21^{\circ} \mathrm{C}$ (García, 2004). Wildlife was surveyed during two periods, one in 2009 and 2010, in which we used six camera stations, and a second period in 2016 and 2017 , in which we used 47 stations. In both cases, the cameras were set randomly along roads, trails and water bodies considering a minimum distance of $500 \mathrm{~m}$ between them. Each station consisted of a camera trap (Scout Guard, Wildview, Bushnell) set at a height of $50 \mathrm{~cm}$ above ground. They were active in a 24 hours period, and were checked periodically and rotated every month. During both survey periods, we worked in sections dominated by rainforest with an average altitude of $412 \mathrm{~m}$ asl.

An index of relative abundance (RA) was calculated as the number of independent records obtained per camera nights during the sampling period. 


\section{RESULTS}

\section{Systematics}

Classis AVES Linnaeus, 1758

Ordo GALLIFORMES Temminck, 1820

Familia CRACIDAE Rafinesque, 1815

Genus Crax Linnaeus, 1758

\section{Crax rubra Linnaeus, 1758}

Examined Material. Sitio Experimental Las Margaritas, Hueytamalco municipality in Central Mexico (2000’05.22” N, 97¹8'28.31” W), Lorena Silverio Polo and Eric Ramírez, 5 pictures.

REMARKS. The pictures clearly depict a cracid of large size, black color with a curly crest, and a yellow knob on its bill. We based our identifications on morphological characters, all of which fit the description of Crax rubra present in the "Birds of Mexico and Central America" field guide (Van Perlo, 2006).

Genus Penelope Merrem, 1786

\section{Penelope purpurascens Wagler, 1830}

Examined material. Sitio Experimental Las Margaritas, Hueytamalco municipality in Central Mexico (2000’05.22”N, 97¹8'28.31'”W), Lorena Silverio Polo, 1 picture.
REMARKS. The pictures clearly depict a cracid of large size, with bluish bare skin on the face, a bare red dewlap on the throat, with a dark brown plumage and red legs which fit the description of Penelope purpurascens present in the "Birds of Mexico and Central America" field guide (Van Perlo, 2006).

\section{DISCUSSION}

We accumulated a total of 195 camera nights during the first sampling period (2009-2010), during which we obtained five records of the great curassow (Crax rubra) (RA=0.025) (Fig. 2) and none of the crested guan (Penelope purpurascens) (Fig. 3). During the second period (2016-2017) we accumulated a total of 1,089 camera nights and 98 unique records in 16 sites of the great curassow $(\mathrm{RA}=0.089$ ), four chachalaca (Ortalis spp.) records $(\mathrm{RA}=0.003)$, and just one of the crested guan ( $\mathrm{RA}=0.001)$. Other species recorded in the camera traps were white-tailed deer, Odocoileus virginianus (Zimmermann, 1780), raccoons, Procyon lotor (Linnaeus, 1758), and armadillo.

Although both species were previously reported in the region during interviews with local communities in 2003 (Cossió, 2007), there was no field information on their abundance or response to habitat loss despite it being one of the main threats to their survival (Brooks \& Strahl, 2006).

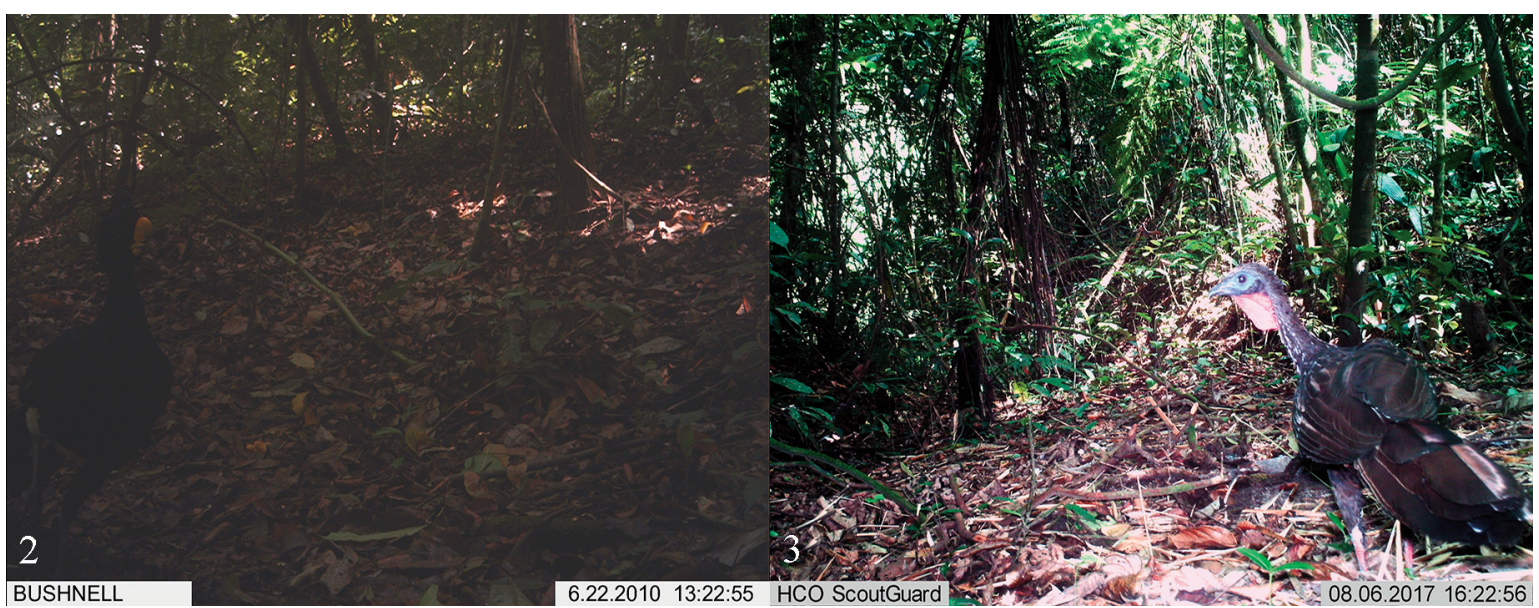

Figure 2. Records of the great currasow (Crax rubra).

Figure 3. Records of crested guan (Penelope purpurascens). 
This is of great importance, as between 2003 and 2016 there was an increase of 5,659 ha in the agricultural surface in the region (SIAP, 2018). Furthermore, communities where Cossio (2007) undertook her fieldwork reported active use of both species, and they considered that the crested guan was scarce and that populations were diminishing while the great curassow was absent in some areas. In the case of the crested guan, the closest records can be found at $16.5 \mathrm{~km}$ and 22.62 $\mathrm{km}$ to the southeast (Teziutlán) and $16.10 \mathrm{~km}$ to the southwest (Hueyapan) (Gonzalez-García et al., 2012; GBIF, 2016), while the closest record for the great curassow corresponds to a sighting from 1942 in the municipality of Huauchinango, which is located at $69.75 \mathrm{~km}$ (eBird, 2018).

Despite the fact that previous studies have estimated the density of both species along their range, such estimates are not considered a credible predictor of local density, as this may vary due to differences in habitat structure and variation in resource distribution or abundance (Kattan et al., 2016). Additionally, areas of high density do not necessarily represent suitable habitats for species on account of the fact that bird species may become established in marginal habitats due to a variety of factors (Kattan et al., 2016). Nevertheless, for some species, as the great curassow, density reflects hunting pressure in the area (Baur, 2008). For that species, there are densities of $1.4 \mathrm{birds} / \mathrm{km}^{2}$ in protected areas (Eisermann, 2004) while in fragmented areas densities vary from 0.4-1.2 birds $/ \mathrm{km}^{2}$ (Vaughan, 1983; McCoy, 1997) which could be due hunting effects or habitat loss. Similarly, for the crested guan, densities in protected areas range from $6-28 \mathrm{birds} / \mathrm{km}^{2}$ and in areas open to hunting they vary between 2 and 7 birds $/ \mathrm{km}^{2}$ (Baur, 2008). Since relative abundance can often be related to density, we consider that our results are representative of values typical of hunted areas, as communities in the area actively use both species. It is noteworthy that in CE Margaritas, contrary to other areas where both species are present, the abundance of the great curassow is higher than that of the crested guan (Lowery \& Dalquest, 1951; Schaldach, 1963, 1969; Vannini \& Rockstroh, 1997) which could be due to the altitude at which records were obtained. However, we found consistency with previous studies that noted a high frequency of solitary individuals and a morning activity pattern (PérezIrineo \& Santos-Moreno, 2017).
The principal threat for the great curassow is habitat loss (Brooks \& Strahl, 2000; Rios \& Munoz, 2006), as it generates fragmented populations (Howell \& Webb, 1995; Brooks \& Strahl, 2000; Rios \& Munoz, 2006). In our study area, fragmentation has increased due to conversion of rainforest to orange plantations that cover near half of the agricultural surface in the region (42.4\%) (Soler Montcouquiol \& Hernández Plascencia, 2005). Although the great curassow can withstand certain levels of habitat alteration, the species is sensitive to changes in vegetation structure (McCoy, 1997; Radachowsky et al., 2004). Thus, this type of agricultural development might favor the isolation of remnant populations. Furthermore, closeness to human settlements promotes high levels of hunting (Silva \& Strahl, 1991), as both species represent an important source of protein (Baur, 2008). However, there is no up-to-date information on hunting in the area or on habitat alterations that may occur as the species is considered an effective seed disperser (Howe, 1993; Pacheco, 1994), and a reduction in its density may result in changes in forest structure (Moreira et al., 2017).

The records obtained in the CE "Las Margaritas" during both seasons are of great significance as they indicate that the species is still present in the area and that its abundance has not varied despite constant threats. However, the high fragmentation levels in the area prevent the formation of corridors between remnant populations. Thus, available information could help generate a conservation strategy that would promote patch connectivity in such a way that it favors altitudinal and temporal migration among patches (Chaves-Campos, 2003).

\section{ACKNOWLEDGEMENTS}

We would like to thank the support and facilities provided to undertake the present work to the National Institute of Forestry, Agricultural and Livestock Research (INIFAP) and to Volkswagen of México S.A. de C.V for the financial support provided to develop the study of the fauna present in Campo Experimental "Las Margaritas". Also, we would like to thank all the reviewers that have checked the manuscript. 


\section{REFERENCES}

Baur E.H., 2008. Structure of a lowland Neotropical Galliform Bird Guild. Thesis University of Florida, 64 pp.

BirdLife International, 2016. Penelope purpurascens. The IUCN Red List of Threatened Species, 2016: e. T22678376A92770679. DOI: 10.2305/IUCN. UK. 20163.RLT S.T22678376A92770679.en. (Accessed in 15 september 2017).

Brooks D.M., Olmos F. \& Begazo A.J., 1998. Biology and Conservation of the Piping Guans (Aves: Cracidae) (No. 1), Cracid Specialist Group: 59.

Brooks D.M. \& Strahl S.D., 2000. Curassows, guans and chachalacas: status survey and conservation action plan for cracids 2000-2004. IUCN, Gland, Switzerland, $181 \mathrm{pp}$.

Brooks D.M. \& Strahl S.D., 2006. Extinguidos en estado silvestre y críticamente amenazados. In: Brooks D.M. (Eds.) Conserving cracids: the most threatened family of birds in the Americas. Miscellaneous Publications of The Houston Museum of Natural Science, Number 6. Houston, Texas, USA, 30 pp.

Chaves-Campos J., 2003. Changes in abundance of crested guan (Penelope purpurascens) and black guan (Chamaepetes unicolor) along an altitudinal gradient in Costa Rica. Ornitologia Neotropical, 14: 195-200.

Cossio A., 2007. Conocimiento y comparación del uso de la fauna silvestre en dos comunidades del municipio de Hueytamalco, Puebla, Mexico. M.Sc. Dissertation, Instituto de Ecología, Xalapa, Veracruz, México, 187 pp.

Del Hoyo J., Elliot A. \& Sargatal J., 1994. Handbook of the birds of the world. Vol. 2. New World vultures to guineafowl. Lynx Ediciones. Barcelona, España, 638 pp.

Del Hoyo J. \& Motis A., 2004. Updated chapter. In: Delacour J. \& Amadon D. (Eds.), Curassows and related birds. 2nd ed. Lynx Edicions, Barcelona, España and The National Museum of Natural History, New York, New York, 322-476.

eBird, 2018. eBird: Una base de datos en línea para la abundancia y distribución de las aves [aplicación de internet]. eBird, Ithaca, New York. Disponible: http://www.ebird.org. Accessed: 20 april 2018.

Eisermann K., 2004. Estatus de Crax rubra en punta de Manabique. Guatemala: hábitat, tamaño de la población e impacto humano. Boletín del Grupo de Especialistas en Cracidos, 18: 4-8

García E., 2004. Modificaciones al sistema de clasificación climática del Köppen. Instituto de Geografía, Universidad Autónoma de México. México D.F., México, 97 pp.
GBIF Secretariat, 2016. Penelope purpurascens Wagler, 1830, GBIF Backbone Taxonomy. Checklist Datase. DOI: 10.15468/39omei accessed via GBIF.org (Accessed on 15-september-2017).

González-García F. \& Martínez-Morales M.A., 2010. Ficha técnica de Penelope purpurascens. In: Escalante-Piego P. (Eds.), Fichas sobre las especies de aves incluidas en Proyecto de Norma Oficial Mexicana PROY-NOM-059-ECOL-2000. Parte 1. Instituto de Biología, UNAM. Bases de datos SNIB-CONABIO. Proyecto No. W007. México, D.F.

González-García F., Pérez-Solano L.A., Ramírez-Bravo O.E., Mandujano S., Ramírez-Julián R., Reyes Macedo G. \& Guillén-Servent A., 2012. Localidades adicionales en la distribución geográfica de la pava cojolita (Penelope purpurascens) en Puebla y Oaxaca, México. Huitzil, 13: 61-67.

Hernández-Pérez E., Martínez-Morales M.A., TobónSampedro A., Pinilla-Buitrago G., López M.S. \& Reyna-Hurtado R., 2014. Registros Notables que Amplían la Distribución Conocida de dos Especies de Crácidos (Aves: Galliformes) en la Península de Yucatán, México. Ornitología Neotropical, 25: 291301.

Howe H.F., 1993. Aspects of variation in a Neotropical seed dispersal system. Vegetatio 107 1: 149-162. https://doi.org/10.1007/BF00052218

Howell S.N.G. \& Webb S., 1995. A guide to the birds of Mexico and northern Central America. Oxford University, Press. New York, EUA, 1010 pp.

INEGI (Instituto Nacional de Estadística y Geografía), 2007. Carta de Uso de Suelo y vegetación Serie IV www.inegi.org.mx/geo/contenidos/recnatu/usodesuel o/default.aspx (Accessed on 18 october 2017). Servicio de Información Agroalimentaria y Pesquera (SIAP), 2018. http://infosiap.siap.gob.mx/gobmx/ Siacon_datos_Abiertos.php Accessed on 18-April2018.

Kattan G.H., Muñoz M.C. \& Kikuchi D.W., 2016. Population densities of curassows, guans, and chachalacas (Cracidae): Effects of body size, habitat, season, and hunting. The Condor, 118: 24-32. DOI: 10.1650/ CONDOR-15-51.1.

López R.R., Silvy N.J., Peterson M.J., Baur E.H., González-García F. \& Brooks D.M., 2014. Chachalacas, hocofaisanes y pavas. In: Valdez R. \& Ortega A. (Eds.), Ecología y Manejo de Fauna Silvestre en México. Colegio de Postgraduados, Univ. Autónoma de Chapingo, Instituto Interamericano de Cooperación para la Agricultura, Texcoco, México,121145.

Lowery G.H. \& Dalquest W.W., 1951. Birds from the state of Veracruz Mexico (Vol. 3). University of Kansas. Kansas, USA, 117 pp. 
McCoy M., 1997. Country report on cracids of Costa Rica. In: Strahl S.D., Beaujon S., Brooks D.M., Begazo A.J., Sedaghatkish G. \& Olmos F. (Eds.), The Cracidae: their biology and conservation. Hancock House. Blaine. Washington, pp. 298-313.

Moreira J.I., Riba-Hernández P. \& Lobo J.A., 2017. Toucans (Ramphastos ambiguus) facilitate resilience against seed dispersal limitation to a large-seeded tree (Virola surinamensis) in a human-modified landscape. Biotropica, 49: 502-510. DOI: 10.1111/btp. 12427.

Pacheco S.C.C., 1994. Hábitos alimentarios y uso estacional de hábitat de la pava crestada (Penelope purpurascens) en el bosque seco tropical, Parque Nacional Santa Rosa, Costa Rica. Tesis de Maestría. Universidad Nacional. Programa Regional en Manejo de Vida Silvestre para Mesoamérica y el Caribe. Heredia, Costa Rica. 80 pp.

Peres C.A., 2000. Effects of subsistence hunting on vertebrate community structure in Amazonian forests. Conservation Biology 14: 240-253. DOI: 10.1046/j. 1523-1739.2000.98485.x

Pérez-Irineo G. \& Santos-Moreno A., 2017. Occupancy, relative abundance, and activity patterns of great curassow (Crax rubra) in Southeastern Mexico. Ornitología Neotropical, 28: 313-320.

Radachowsky J., Garcla R., Cordova M., Aguirre O., Marroquin C., Dubon T., Cordova F., Funes S., Lopez J., Garcla G., Oliva F., Orellana G., Tut H., Manzaneros A., Cordova E. \& Hernandez P., 2004. Effects of certified logging on wildlife in community and industrial forest concessions of northern Guatemala. The Wildlife Conservation Society. New York. New York. EUA. 77.

Rios M.M. \& Munoz M.C., 2006. Great curassow (Crax rubra). In: Brooks D.M., Cancino L. \& Pereira S.L., (Eds.), Conserving cracids: the most threatened family of birds in the Americas. Miscellaneous Publication of the Houston Museum of Natural Science. Number 6. Houston. Texas, pp. 104-108.
Schaldach W.J., 1963. The avifauna of Colima and adjacent Jalisco, México Procedings of the Western Foundation of Vertebrate Zoology, 1: 1-100.

SEMARNAT (Secretaria de medio ambiente y recursos naturales), 2010. Norma Oficial Mexicana NOM059-SEMARNAT 2010. Protección ambiental-Especies nativas de México de flora y fauna silvestre-Categorías de riesgo y especificaciones para su inclusión, exclusión o cambio-Lista de especies en riesgo. Publicado en el Diario Oficial de la Federación. 30 de diciembre de 2010, Segunda sección, Mexico, DF, 78 pp.

SEMARNAT (Secretaria de medio ambiente y recursos naturales), 2011. El medio ambiente en México, disponible en: www.semarnat.gob.mx Accessed on 17 october 2017.

Silva J.L. \& Strahl SD., 1991. Human impact on populations of chachalacas, guans, and curassows (Galliformes: Cracidae) in Venezuela. In: Robinson J.G. \& Redford K.H. (Eds.), Neotropical wildlife use and conservation. University of Chicago Press, Chicago, USA, pp. 36-52.

Soler Montcouquiol R. \& Hernández Plascencia J.A., 2005. Producción y comercialización de la naranja: caso región Acateno, Hueytamalco en el Estado de Puebla, México. Revista Mexicana de Agronegocios, 9: 510-519.

Van Perlo B., 2006. Birds of Mexico and Central America. Princeton University Press, Princeton, New Jersey, $336 \mathrm{pp}$.

Vannini J.P. \& Rockstroh P., 1997. The status or cracids in Guatemala. In: Strahl S.D., Beaujon S., Brooks D.M., Begazo A.J., Sedaghatkish G. \& Olmos F. (Eds.). The Cracidae: their Biology and Conservation. Hancock House Publ., Washington, D.C., pp. 326334.

Vaughan C., 1983. Change in dense forest habitat for endangered wildlife species in Costa Rica from 19401977. Editorial. Universidad Nacional, Heredia, Costa Rica. DOI: 10.22458/urj.v3i1.213. 